Utah State University

DigitalCommons@USU

$5-24-2021$

\title{
Case Studies in the Classroom: Assessing a Pilot Information Literacy Curriculum for English Composition
}

\author{
Rachel Wishkoski \\ Utah State University \\ Katie Strand \\ Utah State University \\ Bret Crane \\ Utah State University \\ Deanna Allred \\ Utah State University \\ Diana J. Meter \\ Utah State University
}

Follow this and additional works at: https://digitalcommons.usu.edu/lib_pubs

Part of the Education Commons, and the Library and Information Science Commons

\section{Recommended Citation}

Wishkoski, R., Strand, K., Sundt, A., Allred, D. and Meter, D.J. (2021), "Case studies in the classroom: assessing a pilot information literacy curriculum for English composition", Reference Services Review, Vol. 49 No. 2. https://doi.org/10.1108/RSR-01-2021-0004

This Article is brought to you for free and open access by the Libraries at DigitalCommons@USU. It has been accepted for inclusion in Library Faculty \& Staff Publications by an authorized administrator of DigitalCommons@USU. For more information, please contact digitalcommons@usu.edu.

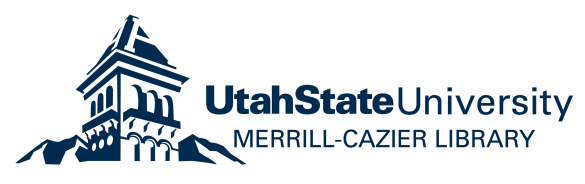




\title{
Case studies in the classroom:
}

\section{Assessing a pilot information literacy curriculum for English composition}

\author{
Rachel Wishkoski, Katie Strand, Alex Sundt, Deanna Allred, and Diana J. Meter
}

Utah State University, Logan, Utah, USA

Post-print of article published in:

Reference Services Review, Vol. 49, Issue 2, https://doi.org/10.1108/RSR-01-2021-0004

\section{Structured abstract}

Purpose: This mixed-methods study assesses a pilot library curriculum in a general education English composition course. Case-based learning (CBL), a form of problem-based learning (PBL), was used to scaffold information literacy skills and concepts across library instruction sessions. This article explores the approach's impact on student learning and engagement. Design/methodology/approach: Participants were enrolled in four sections of an undergraduate composition course. Two sections were taught with the CBL library curriculum, and two with the standard library curriculum as a control. Pretest/posttest surveys included quantitative and qualitative measures to assess students in several areas of information literacy. Weekly reflections from a subsample of students were analyzed, and the research team conducted structured classroom observations and teaching reflections.

Findings: Quantitative survey results did not support the hypotheses that the CBL curriculum would increase students' confidence and skill levels compared to their control section peers. Although there was no significant difference between sections in measured information literacy outcomes, students generally agreed that the case studies used in the CBL curriculum taught skills applicable to their research. Teaching observation data revealed the cohesion of the curriculum across library sessions and increased student engagement in classroom activities. 
However, some of the case studies could be improved, and some limitations in study design point to the need for further research.

Originality: This study addresses a gap in the literature through a mixed-methods assessment of CBL pedagogy using a control group, contributing to an understanding of the role of PBL pedagogies in information literacy curricula.

\section{Keywords}

Case-based learning; Problem based learning; Information literacy; Case studies; English composition; Academic libraries

\section{Article classification}

Research paper

\section{Introduction}

The library and English department at Utah State University have a long history of collaborating to embed information literacy in the composition program, a partnership that includes frequent curriculum evaluation and revision. This paper discusses the effectiveness of case study-based pedagogy for ENGL 2010, “Intermediate Writing: Research Writing in a Persuasive Mode," and share the design and outcomes of a mixed-method assessment of a new curriculum.

\section{English composition at Utah State University}

ENGL 2010 is a General Education requirement at Utah State University, with approximately 100 sections offered each semester in face-to-face, online, and hybrid formats. Skills developed in ENGL 2010 are foundational for upper-division coursework. Thus, ENGL 2010 students are typically first- and second-year students. Librarians provide classroom and online instruction in three information literacy areas (source evaluation, topic development, and 
synthesis) to support students in writing a persuasive research essay on a topic of their choice. Students are evaluated on the effective use of rhetorical strategies in their writing, including engagement with multiple perspectives on their topic.

\section{Pilot curriculum}

The pilot curriculum used a case-based learning (CBL) pedagogy, a type of problembased learning (PBL). Students worked in small groups with a case study that included a person, a source, and context for how the source would be used. The decision to create a CBL curriculum stemmed from an earlier revision of the ENGL 2010 library sequence in which CBL was incorporated into the information evaluation lesson. To better evaluate the effectiveness of $\mathrm{CBL}$, the research team decided to create and assess an updated curriculum that integrated case studies across the entire three-lesson sequence.

Each lesson was designed for a standard 50-minute library class session. Students and the instructor completed pre-work, which varied depending on the lesson but included reading the case studies, a database tutorial, reading and annotating articles, and a lecture introducing the concept of synthesis. At the beginning of the first session, students were divided into groups of four or five, in which they stayed for each subsequent session. Each group was assigned a case study.

The case studies reflected a range of source types and research scenarios, including several lighthearted ones, in order to feel more relatable to students' real-world lives and contemporary issues surrounding fake news and misinformation. Case studies and lessons were written collaboratively by the research team with feedback from with library student employees. Our five case studies were:

- Quoting a piece from a newspaper's editorial board to lobby a senator. 
- Citing a popular sports journalism website in an ENGL 2010 persuasive essay.

- Referencing a peer-reviewed but relevant scholarly article to petition city council.

- Using a satirical website to back a business plan.

- Retweeting a popular blog to share health advice on social media.

As Kumar and Refaei (2013) explain, "Making connections between real world and classroom contexts is vital to effective PBL pedagogy”(p.72). By framing lessons around fictional scenarios rather than their chosen topics, we hoped to encourage students to experiment with different research strategies and approach research with more objectivity. Each lesson began with a short lecture to introduce a concept or skill, followed by small group discussions and activities centered around the case studies. For more information about our CBL curriculum, see Strand et al. (in press).

\section{Literature Review}

\section{Problem-based learning and related pedagogies}

Problem-based learning (PBL) is a constructivist pedagogy in which students engage in "focused, experiential learning organized around the investigation, explanation, and resolution of meaningful problems" (Black and Allen, 2019, p.100). Constructivist approaches center students' experience and "active sense-making," recognizing that learning occurs through the process of integrating prior knowledge with information from new contexts (Black and Allen, 2019, p.100). Initially developed in the 1960s for medical education, PBL has been broadly adapted to various learning contexts. Barrows' (1996) foundational article defined problembased learning as student-centered and self-directed, with problems and problem-solving forming "the organizing focus and stimulus for learning." Furthermore, teachers serve as "facilitators or guides" for learning in small student groups (p.5). PBL has been characterized further as 
allowing students to connect with relevant examples (Gijbels et al., 2005b, p.76) that require messy, active investigation, rather than "well-structured problems or solutions" (Barefoot, 2018, p.253).

Case-based learning (CBL) is a form of PBL wherein more "tightly-focused mini-cases" present "problems or dilemmas faced by the character(s) in the narrative, calling upon the students' use of information gathering and decision-making skills in identifying key issues and postulating possible solutions" (Carder et al., 2001, p.181). Drawing on the work of Baeten et al. (2013), Black and Allen offered a helpful description that guided our approach: "Case-based learning is intended to bridge theory and practice by having students actively explore solutions to authentic tasks in cooperation with peers and with coaching from the instructor" (2019, p.100). PBL in composition and writing instruction

Beckelhimer et al. (2007) noted that PBL has been applied in various writing instruction contexts and supports students' critical thinking skills, ability to work in groups, and sense of a course's "real-world value" (p.4). Through its emphasis on learning in new contexts, PBL can also serve as a bridge between high school and college-level writing courses (p.6). There are several examples of writing courses where information literacy is woven into an overarching PBL pedagogy, including: instructor-designed information literacy lessons (Rosinski and Peeples, 2012); a librarian-designed lesson integrated within a problem-based writing curriculum (Kumar and Refaei, 2013); and a collaborative redesign of a technical writing course by an instructor and librarian team (Diamond, 2019).

While there is a gap in quantitative studies of PBL in writing courses, a recent study by Golden (2018) examined scenario-based learning (SBL, a type of PBL) in a composition and Rhetoric course. The study reported statistically significant student performance improvements 
and growth in critical thinking. However, improvements only occurred when scenario-based prompts were extended from in-class activities to essay assignments: "The low-stakes SBL activities alone were not enough to help students reach that meaning-making stage of learning where they see the application to multiple contexts...one well-designed SBL activity would [not] spark recognition in the usefulness of the course material" (p.6).

\section{$P B L$ in information literacy instruction}

Goodsett (2020) highlighted PBL and related pedagogies as instructional approaches that can stimulate metacognition. Because PBL offers an approach to learning that is active, collaborative, and interconnected with real-world examples and sociocultural learning theory, library instructors have long seen it as a viable pedagogical framework (Wang, 2007). This includes one-shot, general education contexts (Carbery, 2011; Enger et al., 2002; Kenney, 2008) and discipline-specific courses (Cook and Walsh, 2012; D'Angelo, 2001; Diekema et al., 2011; Milczarski and Maynard, 2015). Applications of PBL range from a single in-class activity joining critical information literacy and multicultural education (Barefoot, 2018) to a five-session sequence in a general education course (Wenger, 2014).

Library instructors have described many benefits of PBL, especially higher student engagement in active, peer-directed learning and growth in critical thinking. Though many reports draw on informal instructor observations, some studies have used posttest-only (Carbery, 2011) and pretest-posttest student self-evaluations (Cook and Walsh, 2012; Roberts, 2017; Spackman and Camacho, 2009). There are limited examples of controlled studies, and in some cases (e.g., Macklin, 2008), quantitative results have been statistically insignificant, while qualitative assessments can yield different insights. For example, Macklin's (2008) think-aloud protocols and semi-structured interviews revealed commonalities among successful students in a 
PBL context. Other approaches include analysis of student research journals (Diekema et al., 2011), reflection papers (Cook and Walsh, 2012; Diekema et al., 2011), and final papers.

Sound pedagogical praxis also turns the lens of assessment on the instructor, who, in the case of PBL, must act more as a facilitator than a lecturing expert. Macklin (2001) emphasized the importance of library instructor reflection, suggesting both journaling and peer observation.

\section{Methods}

The study targeted four sections of ENGL 2010, taught in fall 2019 by two different English department instructors. Participants were undergraduate students, age 18 or older. Two sections received the pilot CBL curriculum and two received the standard curriculum. -- The standard curriculum is used across ENGL 2010 sections and employs case studies for the first lesson (source evaluation) only. Students do not return to the case studies in later sessions on searching and synthesizing. Because of instructor preference, the sections with the standard curriculum received library instruction near the end of the semester, while the pilot sections received instruction spread across the semester. Forty-five students were enrolled in each condition (experiment and control) for a total of 90 students. Student demographics were not collected to maintain student anonymity and privacy in accordance with our IRB protocol. ${ }^{1}$ Three main research questions guided assessment of the new curriculum:

- How does the CBL curriculum impact students' confidence and abilities when evaluating information, searching for information, and synthesizing sources?

- What research skills do students struggle with and how can the curriculum better address these struggles?

\footnotetext{
${ }^{1}$ This study was approved by the Utah State University Institutional Review Board, Protocol \#10444.
} 
- How effective is case-based, problem-based learning in engaging ENGL 2010 students in learning information literacy skills?

We collected quantitative and qualitative data using multiple assessments designed to provide a richer sense of student experiences and the impact of CBL on student learning, while also providing self-reflection and pedagogical takeaways as instructors. Assessment methods included a pre/posttest survey, analysis of student reflection papers, classroom observations, and instructor reflections.

Surveys

The survey was designed to answer specific questions related to our overarching research questions:

- What is our ENGL 2010 student baseline before library instruction?

- Did CBL students like using case studies, and did they think the case studies taught them skills applicable to their own research?

- Did CBL students rate usefulness of library instruction higher than their control section peers?

- Is CBL students' self-reported understanding of how to combine skills into an integrated research process higher than that of their control section peers?

- Do CBL students' self-assessed confidence levels in four areas of information literacy increase more than their control section peers?

The use of a control group allowed for direct comparison between the two pedagogical approaches. We designed optional, anonymous pretest and posttest surveys using Qualtrics and administered the surveys during the class meetings directly before the first and after the last library session for each of the four designated ENGL 2010 sections. To reduce the potential for 
coercion, a library teaching assistant facilitated survey recruitment, consent, and administration, and neither the course instructor nor any members of the research team were present. Individual participants' responses were linked between the pre- and posttests using a six-digit code students generated when entering their responses. This allowed the survey data to be meaningful longitudinally.

Surveys consisted of closed and open-ended questions (Appendix A). In the first section of the survey, students first rated their confidence in four information literacy skills: using library resources, evaluating the credibility of information, finding appropriate information for a specific research topic, and combining information (synthesis) in writing. They also rated their level of agreement with the statement "I think library sessions for this class will be useful for me," with an open-ended space to explain why. These questions used a 5-point Likert scale, with 1 being "strongly disagree" and 5 being "strongly agree." The second section of the survey asked students to first describe areas where they struggled when searching for information online and then to demonstrate their skills in three areas. Students listed strategies for evaluating information, discussed ways of narrowing a broad search, and explained why they selected one sample paragraph as a better example of synthesis than another.

The posttest survey was identical to the pretest with two exceptions. First, the posttest included an additional question that asked all students to rate their agreement with the statement, "I understand how to combine skills learned in each library session into a single research process." Second, students in the experimental CBL sections also rated their agreement with statements about their enjoyment and the usefulness of the case studies with an optional space to explain why they provided the rating they did. We hypothesized that CBL students would find library instruction more useful and report an increased understanding of research as an integrated 
process, and higher confidence levels with individual skills compared to students who received the traditional curriculum.

The remaining assessment methods - student reflection papers, classroom observations, and teaching reflections - focused on our CBL sections only because the instruction was different. Librarians and composition instructors regularly reflect on and discuss the standard ENGL 2010 curriculum. Teaching observations and conversation about the CBL lessons included comparisons to current and prior semesters' experiences teaching the standard curriculum. Student reflection papers were an established part of the CBL instructor's course already and were not library specific. They were therefore a more authentic space to see if and how library lessons were mentioned outside of the pre/posttest. They were not part of the control section instructor's course design.

Student reflection papers

Each week, the course instructor for the CBL sections asked students to write a short reflection paper on the following prompt: "What three ideas from class discussion, class readings, or connections from class to your broader life made the most impact on you this week?" These papers are written for the instructor and are graded. Depending on the participant, this could induce a response bias where the papers skew positive due to students wishing to avoid stating negative things about the course. However, we were curious how, if at all, library or information literacy themes would emerge in these reflections unprompted.

We collected reflection papers for each week with scheduled library instruction, three sets of papers total. Students were offered the opportunity to opt-in after their reflection papers had been written. To reduce the potential for coercion, a library teaching assistant recruited and obtained consent for this portion of our study and collected and de-identified papers after final 
grades were posted. We analyzed papers in separate rounds, with one researcher summarizing themes and counting positive and negative impressions of the library curriculum, and the second researcher reviewing to validate.

\section{Classroom observations and reflections}

A member of the research team observed teaching and classroom activity for each library CBL session, recording observations using a template modeled after the University of Texas at El Paso's "Record of Time Allotment in Class" (2006, p.48-49). A secondary section of the template was used to record impressions of overall student engagement levels, highlights of effective moments, and a summary of pedagogical challenges, surprises, and areas for improvement. This allowed us to document what occurred without relying on after-the-fact recall that could be skewed by time, emotion, or other findings. After each CBL session, the librarian co-teacher and the instructor of record also completed this section of the reflection/observation template.

The observer and instructors completed the templates immediately after each session, then spent 15-30 minutes discussing and documenting our takeaways as a team. Reflections often included comparisons to previous semesters in which the teaching team used the standard library curriculum. Observation and reflection data were analyzed together, with three team members using a shared protocol and using a round-robin technique to identify significant trends across all reflections and observations for each lesson. 


\section{Results}

Surveys

Quantitative data were analyzed using R (R Core Team, 2019). Two research team members completed the qualitative analysis of the open-ended survey, dividing the questions, independently coding themes, trading for review, and meeting to synthesize findings.

\section{Quantitative results}

Eighty of the $90(88.9 \%)$ enrolled students (45 in each condition) responded to the quantitative portion of the pretest, and $59(65.5 \%)$ responded to the posttest (Table I). The experimental sections had lower response rates than the control sections, with $64.4 \%$ for the experimental posttest being the lowest response rate by time and condition.

Before library instruction (Table II), student confidence appears highest in finding information and determining credibility. Confidence in the ability to use library resources appears bimodally distributed, with peaks at four ("Somewhat agree") and two ("Somewhat disagree"). Despite students' high self-assessments, the majority of students thought the upcoming library sessions would be useful.

Students indicated their agreement with the statements "I think the library sessions for this class were useful to me" and "I understand how to combine skills learned in each library session into a single research process." There was no statistically significant difference in posttest comparisons between the experimental and control groups for either question, Welch's $t$ $(56.81)=.89, n s$ and Welch's $t(56.79)=.49, n s$, respectively. These results do not support our hypotheses that the CBL curriculum would be perceived as more useful and help students better understand research as a process. 
We ran a 2-way mixed ANOVA across conditions and time points to determine whether student confidence levels in four information literacy areas differed between curricula. Results suggest that confidence increased between the pre- and posttest across these areas, but there was no significant difference between experimental and control conditions (Table III).

In terms of students' attitudes toward the CBL pedagogy, our results showed mixed levels of enjoyment, but general agreement that skills gained from the lessons applied to students' research (Table IV).

\section{Qualitative results}

Student responses to open-ended survey questions provide an important complement to the quantitative data. As in the case of our quantitative items, the experimental group had overall lower response rates, including two key questions asking participants to elaborate on their ratings of the case study approach, which had the lowest response rates of all (46.7\% and $42.2 \%)$.

The responses of those CBL students who did elaborate on their experience offer a more nuanced understanding of the experience and efficacy of a case-study-based curriculum (summarized in Table V). Those who did not like the CBL approach thought that working on their research topics would have been a better use of class time. Some understood the purpose of the case studies but found them too long-winded or like busywork. Responses from two participants represent this perspective:

- "It became somewhat annoying to have to go back to researching something that wasn't even actually real or had any value to me. I think it would be more beneficial to directly go through research on our own and find the learnings through that." 
- "While I learned skills to be applied due to the case studies and working in groups it was harder to transfer the information learned into my own writing than if we were to just focus on our own writing from the first place."

Those who liked the CBL approach thought the case studies offered a lower-stakes opportunity to learn and practice the research process without worrying about their assignment or committing to their research topic. These students enjoyed the activities and working with their peers, though some expressed that they did not like their assigned case study. Two students representing this perspective responded:

- 'Learning and using research skills for another person's idea helped me learn how to navigate academic search engines and how to find sources that I desired. The low-stress environment of the library, and the help of others made the idea of doing academic research much less intimidating and it actually was a fun experience.”

- "Using a claim that was already provided for us and had some research done was a great way to get our minds thinking and understanding the skill we were supposed to be learning."

The open-ended questions shed light on students' struggles when searching for and evaluating information, their strategies for narrowing a search and evaluating sources, and their understanding of synthesis. The codebook can be found in Appendix B. Notable changes in the frequencies of codes by time and condition are presented in Table VI and discussed question-byquestion below.

Search struggles. Finding relevant information was the most significant area of struggle for students. Although the frequency of this code decreased after library instruction, over $30 \%$ of the responses to this question in both conditions listed this as a challenge. Assessing source 
credibility was another challenge, which persisted after library instruction, particularly for the experiment group. The control group showed a decrease in the frequency of this code from $45.2 \%$ to $6.7 \%$, whereas the experimental group only shifted from $30.6 \%$ to $24.1 \%$, perhaps reflecting the more nuanced discussion of evaluation in the CBL curriculum. This also indicates that evaluation cannot be taught in a single session; instead, these skills and dispositions require ongoing practice and adaptation to different situations.

Both groups reported increased struggles with keyword selection, perhaps due to students gaining more experience with databases and the importance of keywords. Students in the experimental group showed more confidence in sorting and filtering search results, with only $3.4 \%$ listing this as an area of struggle after instruction compared to $10 \%$ of students in the control group. Students mentioned struggling with irrelevant sources and with time-management and motivation to conduct research in both groups' posttest.

Finally, student attitudes and the framing of the research process were reflected in their struggles. $10 \%$ of posttest responses in both groups still mentioned the difficulty of finding "specific" information, which could indicate students struggled with the concept of research as open inquiry versus confirming pre-formed opinions or ideas. In addition, students in the experiment group were more concerned about reading scholarly articles than the control group, reflecting a difference in instructor emphasis and the influence of overall course design in guiding students' approaches to research.

Search strategies. When asked about how to narrow search results, students in both conditions mentioned keywords and database filters more frequently after receiving library instruction. However, students' responses showed a decreased emphasis on focusing the research question itself, with only a single student (from the experimental posttest) mentioning subject 
searching. When discussing adding or modifying keywords to refine searching, students often listed generic changes like impact, effect, and positive or negative outcomes, suggesting that our approach to keyword instruction, which relied on a database tutorial, may not be the best method for teaching this complex skill.

Evaluation strategies. Our data support what we have experienced in the classroom already - ENGL 2010 students arrive with some established evaluation skills, which our instruction needs to acknowledge and build upon. Author credibility, reputation or credibility of the publication venue, and currency of the source were most frequently mentioned across conditions and pre/posttest. After library instruction, mentions of author credibility increased to $86 \%$ in both conditions. Website domain, a factor commonly used in older evaluation criteria, was mentioned by $20-30 \%$ of students in the pretest and decreased in the posttest across conditions, perhaps in favor of more nuanced evaluation approaches.

While assessing bias was a prominent evaluation strategy in our experiment group, fewer students mentioned it after library instruction across conditions. The library curriculum (both control and $\mathrm{CBL}$ ) sought to complicate the idea of bias, discussing bias as a factor that can be mitigated but never really eliminated. This complexity, or perhaps general anxiety about dealing with bias, may explain why students rarely mentioned it as an evaluation strategy.

Investigating a claim outside of the original source and fact-checking were strongly emphasized in our curriculum, but were mentioned infrequently by either condition, even after library instruction. Similar to bias, our evaluation lesson may have complicated the concept, so much so that students may have been discouraged from using lateral reading and other strategies that require close reading and topic engagement, in favor of more tangible criteria like author and source credibility. Relevancy was also more frequently discussed by the experiment group after 
library instruction, which is likely due to the focus on the source's relevance to the researcher in several case studies.

Synthesis explanations. After library instruction, students in both conditions were more successful in selecting the correct example of synthesis, with the experimental group having a $5 \%$ higher success rate compared to the control. Prior to library instruction, students provided vague reasons (e.g., better "flow") for their selections, while posttest responses frequently mentioned more specific indicators, such as “balanced conversation between author's voice and sources." In the CBL curriculum, students worked in groups to write a synthesized paragraph, which may explain the greater emphasis they placed on balanced conversation, while the control group frequently mentioned the author's dominant voice.

\section{Student reflection papers}

Reflection papers were assigned only in the experimental sections. Eight students consented to including their papers included in the study, yielding 24 papers for analysis. Results indicated that the library curriculum had a strong impact on students, with all but one mentioning library activities or concepts at least once. In general, students reflected positively on the lessons, with two students appreciating the applicability of research concepts and skills for other classes and their everyday lives, and three noting that they gained new skills or perspectives on the research process. While several questioned the continued use and value of the case studies, in most cases, students were pleasantly surprised by the conclusion of each lesson. For example, one student reflected:

"In all honesty I almost dreaded the library day. I was not sure if there was anything else that was important for us to learn but it, just like all the other ones, turned out to be very 
beneficial. I do think that the some of the cases made it a little more challenging than it needed to be to complete the assigned work."

As this quote illustrates, some of the case studies were less successful in sustaining student engagement than others, a finding that was also evident in qualitative survey responses and classroom observations.

\section{Classroom observations and instructor reflections}

Instructor reflections, observations, and team debriefs helped foster a shared, reflexive approach to teaching and uncovered ways to improve lesson design. Formal analysis of our reflections/observations revealed group dynamics to be a major factor in determining the success of case-based activities, which relied on students actively engaging in problem-solving as a team. In some cases, most students were active participants, leading to more focused discussions and deeper analysis. In others, strong personalities derailed group discussions, or lack of leadership led to stagnant or unfocused discussions. While some of the quieter groups improved as lessons progressed, others struggled to stay on task.

Some case studies were more effective than others. While both serious and more lighthearted scenarios proved engaging, some topics were too simplistic to elicit meaningful discussions and analysis, particularly if students needed to explore beyond the assigned topics to be successful. Other scenarios were too narrow or failed to interest students from the beginning. The most successful cases typically included a broad or multifaceted topic that provided many fruitful directions to explore, while also being relevant to students with a range of interests and backgrounds. 


\section{Discussion}

\section{Limitations}

The design of this study had several limitations, mainly differences between the experimental and control conditions beyond the case study curriculum. In order to increase the total number of participants, we included sections of ENGL 2010 taught by two different instructors. As instructors have autonomy in their course design, there were differences in assignments (though the final research paper assignment is the same, one instructor required weekly reflection papers while the other did not) and in preference for when in the semester library instruction occurred. Controlling for instructor and timing of instruction would have meant halving our number of participants. Survey data collection did not differ between the CBL and standard curriculum sections, but other methods focused only on the sections using the CBL curriculum. In addition, the response rate for CBL students allowing the inclusion of their reflection papers in the study was very low. Our IRB protocol required an opt-in approach at the end of the term once final grades had been submitted to reduce coercion. The study would have been strengthened by having control and experimental section students complete reflection papers, working with the IRB to find a way to increase response rate for these papers, completing formal teaching observations and reflections in the control sections, and controlling for instructor by extending the study over two semesters. Despite these limitations, this study does - through the use of mixed assessment methods and a control group - expand on the more anecdotal evidence supporting the use of problem-based learning in information literacy instruction, laying the groundwork for additional research into the effectiveness of problem-based learning in the library field. 


\section{Quantifying the impact of PBL pedagogies}

While there was no significant difference between the conditions in terms of measured information literacy outcomes, CBL students generally agreed that the case studies taught them skills applicable to their own research, and many (though not all) liked using the case studies. There is a significant body of literature about assessing PBL pedagogies, including metaanalyses and meta-syntheses, which reveal that non-significant results do not tell the whole story about the efficacy of PBL approaches.

In a foundational article on PBL, Barrows (1996) stated the difficulty of formally assessing differences between PBL and non-PBL students, pointing to general observations by instructors as evidence of pedagogical effectiveness. Barrows also referenced meta-evaluations showing that PBL is not harmful compared to traditional teaching methods, and may be beneficial for the development of problem-solving skills and student engagement. However, over the decades that this pedagogy has been implemented, researchers have debated its effectiveness, with differing conclusions.

Dochy et al. 's (2003) meta-analysis found a positive effect of PBL for student skills (the application of knowledge), but a possible negative effect on students' knowledge base. More importantly, the study identified key moderators of these impacts, including research design, assessment method used, and how PBL is implemented. Gijbels et al. (2005a) argued that the assessment method is not only a moderator, but what is assessed impacts PBL outcome measurements. PBL, they discovered, is most effective when it targets students" "understanding of the principles that link concepts" (p.27). Finally, a meta-synthesis by Strobel and van Barneveld (2009) found that while PBL was less effective than traditional instruction for short- 
term retention, it "was superior [for] long-term retention, skill development and satisfaction of students and teachers" (p.44).

Our quantitative assessment of CBL's efficacy relied on self-report and demonstration and focused only on the short-term. Our qualitative results and teaching observations do suggest benefits for classroom engagement, and our CBL group did not perform worse than the students who received our traditional curriculum. PBL literature both inside and outside of Library and Information Science point to the need for more robust and carefully designed assessments of PBL's effectiveness. This is an area for future research and development for library educators seeking to create more engaging and contextual learning opportunities for students.

\section{Curriculum cohesion and student engagement}

One major benefit of our CBL pedagogy was the through line provided by the case studies. The case studies acted as a common thread connecting discrete lessons into a coherent learning experience, and, we hope, illustrated the interconnectedness and recursive nature of the research process. While not a perfect fit for all students, many valued the chance to practice research skills and explore concepts in the context of a real-world problem. Our views align with those of Rosinski and Peeples (2012) who cautioned that while PBL is not necessarily the best approach for all teaching contexts, it "does offer something special, and that is its quality of initiating instruction with, and then having all learning emerge out of, a well crafted problem" (p.25).

Although some of our case studies could be improved, the CBL curriculum was generally more engaging for students. By working in groups over three lessons, students built rapport and became invested in their cases, encouraging broader participation, and often, deeper discussion and problem-solving during group activities. 


\section{Insights about students and reflective teaching practice}

In addition to exploring the application of CBL to information literacy, this project shed light on our students and their research processes. Student survey responses showed us how much students value the opportunities to work on their research and ask questions with librarians there to help. Students bring existing skills into the library classroom, particularly methods for evaluating information, and appreciate help with application, further development, and lessfamiliar concepts such as synthesis.

As Hulseberg and Versluis explained, "students' confidence in information literacy may not coincide with their actual abilities" (2017, p.22). Assessments of confidence as well as performance are necessary, and mixed-methods assessment yields additional insights. For example, student reflection papers provided perspectives into student thinking that can be rarer for librarians to witness, and helped us re-think how to situate library lessons in the whole experience of the course.

This project also reinforced how assessment connects to reflective practice as instructors. It was meaningful to debrief about teaching, intentionally reflect on pedagogy, and dive deeper into how students experienced our new curriculum. In this way, we established a teaching community of practice that we hope will continue to flourish between the library and English composition program, nurturing a sense of collaboration and helping interconnect information literacy and writing learning outcomes.

\section{Conclusion}

The COVID-19 pandemic dramatically shifted our plans for the English composition curriculum at Utah State University, necessitating a rapid pivot to online instruction that made it difficult to incorporate CBL. However, with more time to design, a CBL curriculum could work 
in an online environment, which is an area for further development. Our current study could have been strengthened by expanding it over more semesters and including a comparative evaluation of students' final research papers in our methods, which could have provided a fuller picture of the effectiveness of CBL for information literacy instruction. With online instruction likely to play a larger role across higher education, assessment and reflection can help expose questions we may not be asking about how to motivate students better and create more opportunities for genuine learning in this new reality.

Problem-based learning offers one approach that may help move information literacy from skill-based instruction toward a more authentic exploration of concepts. While we deliberately included diverse racial, ethnic, and gender identities in our case studies, there is rich potential to use CBL to intentionally teach cultural literacy and empathy through a critical information literacy lens, as Maria Barefoot has demonstrated (2018). It is essential to situate information literacy in the real world, including today's chaotic information landscape where the stakes are higher than ever. As invitations to learning, case studies are examples of leveraging the power of story as "a vital tool in teaching complicated and emotional topics" (p.252). By offering students space to step into the shoes of another, we can offer them an opportunity to hone a more critical stance in relation to a bewildering world.

\section{Acknowledgments}

The authors would like to thank the library student employees and interns who helped with curriculum development: Maddie Thomas, Madeleine Bell, Luke White, and Alyssa Begaye. We also thank our colleague, Jessica Sandberg, who helped with recruitment for this study, and the instructor who was willing to have his sections of ENGL 2010 participate as our control group. There were no funding sources for this research. 


\section{References}

Baeten, M., Dochy, F., and Struyven, K. (2013), 'Enhancing students' approaches to learning: the added value of gradually implementing case-based learning", European Journal of Psychology of Education, Vol. 28 No. 2, pp.315-336. https://doi.org/10.1007/s10212012-0116-7.

Barefoot, M.R. (2018), "Identifying information need through storytelling”, Reference Services Review Vol. 46 No. 2, pp.251-263. https://doi.org/10.1108/RSR-02-2018-0009.

Barrows, H.S. (1996), "Problem-based learning in medicine and beyond: a brief overview", New Directions for Teaching and Learning, Vol. 68, pp.3-12. https://doi.org/10.1002/t1.37219966804.

Beckelhimer, L., Hundemer, R., Sharp, J., and Zipfel, W. (2007), "Problem-based composition: the practical side", The CEA Forum, Vol. 36 No. 1, pp.1-7.

Black, S. and Allen, J.D. (2019), "Part 9: planning instruction", The Reference Librarian, Vol. 60 No. 2, pp.93-108. https://doi.org/10.1080/02763877.2019.1571469.

Carbery, A. (2011), "Introducing problem-based learning into one-shot information literacy instruction at Waterford institute of technology libraries", SCONUL Focus, Vol. 53, pp.30-33.

Carder, L., Willingham, P., and Bibb, D. (2001), "Case-based, problem-based learning: information literacy for the real world," Research Strategies, Vol. 18 No. 3, pp.181-190. https://doi.org/10.1016/S0734-3310(02)00087-3.

Cook, P. and Walsh, M.B. (2012), "Collaboration and problem-based learning: integrating information literacy into a political science course", Communications in Information Literacy, Vol. 6 No. 1, pp.59-72. https://doi.org/10.15760/comminfolit.2012.6.1.118.

D’Angelo, B.J. (2001), "Using source analysis to promote critical thinking”, Research Strategies, Vol. 18 No. 4, pp.303-309. https://doi.org/10.1016/s0734-3310(03)00006-5.

Diamond, K. (2019), "Problem-based learning and information literacy: revising a technical writing class", Veach, G. (Ed.), Teaching Information Literacy and Writing Studies: Volume 2, Upper-Level and Graduate Courses, Purdue University Press, West Lafayette, IN, pp. 157-168.

Diekema, A.R., Holliday, W., and Leary, H. (2011), "Re-framing information literacy: problembased learning as informed learning”, Library \& Information Science Research, Vol. 33 No. 4, pp.261-268. https://doi.org/10.1016/j.lisr.2011.02.002. 
Dochy, F., Segers, M., Van den Bossche, P. and Gijbels, D. (2003), "Effects of problem-based learning: a meta-analysis", Learning and Instruction, Vol. 13 No. 5, pp.533-568. https://doi.org/10.1016/S0959-4752(02)00025-7.

Enger, K.B., Brenenson, S., Lenn, K., MacMillan, M., Meisart, M.F., Meserve, H., and Vella, S.A. (2002), "Problem-based learning: evolving strategies and conversations for library instruction", Reference Services Review, Vol. 30 No. 4, pp.355-358. https://doi.org/10.1108/00907320210451367.

Gijbels, D., Dochy, F., Van den Bossche, P., and Segers, M. (2005a). "Effects of problem-based learning: a meta-analysis from the angle of assessment", Review of Educational Research, Vol. 75 No. 1, pp.27-61. https://doi.org/10.3102/00346543075001027.

Gijbels, D., Van de Watering, G., and Dochy, F. (2005b), "Integrating assessment tasks in a problem-based learning environment", Assessment \& Evaluation in Higher Education, Vol. 30 No. 1, pp.73-86. https://doi.org/10.1080/0260293042003243913.

Golden, P. (2018), “Contextualized writing: promoting audience-centered writing through scenario-based learning", International Journal for the Scholarship of Teaching and Learning, Vol. 12 No. 1, pp.1-9. https://doi.org/10.20429/ijsotl.2018.120106.

Goodsett, M. (2020), "Best practices for teaching and assessing critical thinking in information literacy online learning objects", The Journal of Academic Librarianship, Vol. 46 No. 5, pp.102-163. https://doi.org/10.1016/j.acalib.2020.102163.

Hulseberg, A. and Versluis, A. (2017), "Integrating information literacy into an undergraduate geography research methods course", College \& Undergraduate Libraries, Vol. 24 No. 1, pp.14-28.

Kenney, B.F. (2008), "Revitalizing the one-shot instruction session using problem-based learning”, Reference \& User Services Quarterly, Vol. 47 No. 4, pp.386-391. https://doi.org/10.5860/rusq.47n4.386.

Kumar, R. and Refaei, B. (2013), "Designing a problem-based learning intermediate composition course", College Teaching, Vol. 61 No. 2, pp.67-73. https://doi.org/10.1080/87567555.2012.741079.

Macklin, A.S. (2001), "Integrating information literacy using problem-based learning”, Reference Services Review, Vol. 29 No. 4, pp.306-314. https://doi.org/10.1108/eum0000000006493.

Macklin, A.S. (2008), “A PBL approach for teaching complex Information and Communication Technology (ICT) skills in higher education”, Community \& Junior College Libraries, Vol. 14 No. 4, pp.233-49. https://doi.org/10.1080/0276391080233638. 
Milczarski, V. and Maynard, A. (2015), "Improving information literacy skills for psychology majors: the development of a case study technique", College \& Undergraduate Libraries, Vol. 22 No. 1, pp.35-44. https://doi.org/10.1080/10691316.2015.1001242.

R Core Team (2019), "R: A language and environment for statistical computing”, $R$ Foundation for Statistical Computing, Vienna, Austria, available at: https://www.R-project.org/.

Roberts, L. (2017), "Research in the real world: improving adult learners web search and evaluation skills through motivational design and problem-based learning", College \& Research Libraries, Vol. 78 No. 4: 527-551. https://doi.org/10.5860/crl.78.4.527.

Rosinski, P. and Peeples, T. (2012), "Forging rhetorical subjects: problem-based learning in the writing classroom", Composition Studies, Vol. 40 No. 2, pp.9-33.

Spackman, A. and Camacho, L. (2009), "Rendering information literacy relevant: a case-based pedagogy", Journal of Academic Librarianship, Vol. 35 No. 6, pp.548-554.

https://doi.org/10.1016/j.acalib.2009.08.005.

Strand, K., Wishkoski, R., Sundt, A., and Allred, D. (in press), “A tale of five case studies: reflections on piloting a case-based problem-based learning curriculum in English composition", Barefoot, M., Parme, S., and Woods, E. (Eds.), Once Upon A Time in The Academic Library: Storytelling Skills for Librarians, Association of College \& Research Libraries, Chicago, IL.

Strobel, J., and Van Barneveld, A. (2009), "When is PBL more effective? A meta-synthesis of meta-analyses comparing PBL to conventional classrooms." Interdisciplinary Journal of Problem-Based Learning, Vol. 3 No. 1, pp.44-58. https://doi.org/10.7771/1541$\underline{5015.1046 .}$

University of Texas at El Paso (2006), "Record of time allotment in class", Roberson, W. (Ed.), Peer Observation and Assessment of Teaching: A Resource Book for Faculty, Administrators, and Students Who Teach, El Paso, TX, pp.48-49.

Wang, L. (2007), "Sociocultural learning theories and information literacy teaching activities in higher education", Reference \& User Services Quarterly, Vol. 47 No. 2, pp.149-158. https://doi.org/10.5860/rusq.47n2.149.

Wenger, K. (2014), "Problem-based learning and information literacy: a natural partnership", Pennsylvania Libraries: Research \& Practice, Vol. 2 No. 2, pp.142-154. https://doi.org/10.5195/palrap.2014.61. 


\section{Appendix A: Survey items}

\section{Pre- and posttest items}

Choose the response that matches how much you agree or disagree with the following statements.

(5-point Likert scale, where 1 is "Strongly disagree," 2 is "Somewhat disagree," 3 is "Neither agree nor disagree," 4 is "Somewhat agree," and 5 is "Strongly agree.")

1. I am confident in my abilities to use library resources.

2. I am confident in my abilities to tell if information is credible.

3. I am confident in my abilities to find appropriate information for a specific topic.

4. I am confident in my abilities to meaningfully combine my research into a cohesive paper.

5. I think the library sessions for this class will be/were useful for me.

6. Why or why not?

Provide short answers to the following questions.

7. What do you struggle with most when searching for information online?

8. List 3 strategies for evaluating the credibility or relevance of information.

9. You're writing a paper on the impact of technology on children. But when you search the words technology and children in the library database Academic Search Ultimate, you get 61,000 results! What are some ways you can narrow this down?

10. Which paragraph is a better example of synthesis?

- Paragraph A

- Paragraph B

- I'm not sure.

11. Why?

\section{Additional posttest items}

(5-point Likert scale, where 1 is "Strongly disagree," 2 is "Somewhat disagree," 3 is "Neither agree nor disagree," 4 is "Somewhat agree," and 5 is "Strongly agree.")

1. I understand how to combine skills learned in each library session into a single research process.

For CBL sections only:

2. I liked using case studies to learn research skills.

- Tell us more:

3. My case study taught me skills I can use in my own research.

- Tell us more: 


\section{Appendix B: Codebook for open-ended survey questions}

\begin{tabular}{|c|c|c|c|}
\hline Search Struggles & Search Strategies & Evaluation Strategies & Synthesis Explanations \\
\hline $\begin{array}{l}\text { Finding relevant } \\
\text { information }\end{array}$ & $\begin{array}{l}\text { Be more specific, narrow } \\
\text { focus, adjust scope }\end{array}$ & Author's credibility & $\begin{array}{l}\text { Balanced conversation } \\
\text { between author's voice } \\
\text { and sources }\end{array}$ \\
\hline Finding credible sources & Add or modify keywords & $\begin{array}{l}\text { Reputation or credibility } \\
\text { of publication }\end{array}$ & $\begin{array}{l}\text { Author's voice is } \\
\text { dominant }\end{array}$ \\
\hline $\begin{array}{l}\text { Finding and reading } \\
\text { scholarly articles }\end{array}$ & Phrase search & Website domain & Combining of ideas \\
\hline $\begin{array}{l}\text { Selecting the right } \\
\text { keywords }\end{array}$ & $\begin{array}{l}\text { Use subject search instead } \\
\text { of keyword search }\end{array}$ & $\begin{array}{l}\text { Bias in the author, article, } \\
\text { or publication }\end{array}$ & Citing multiple sources \\
\hline $\begin{array}{l}\text { Sorting through, filtering } \\
\text { too many results }\end{array}$ & Use boxes & Currency & Correctly cite their sources \\
\hline $\begin{array}{l}\text { Choosing/focusing my } \\
\text { paper topic }\end{array}$ & $\begin{array}{l}\text { Use database filters or } \\
\text { tools }\end{array}$ & $\begin{array}{l}\text { Investigate claim through } \\
\text { other sources }\end{array}$ & Good "flow," easy to read \\
\hline $\begin{array}{l}\text { Knowing when I have } \\
\text { enough sources }\end{array}$ & Search in another place & $\begin{array}{l}\text { Fact check the article's } \\
\text { sources }\end{array}$ & $\begin{array}{l}\text { Includes personal } \\
\text { experience }\end{array}$ \\
\hline $\begin{array}{l}\text { Finding a specific piece of } \\
\text { information }\end{array}$ & Boolean operators & Quality of writing & $\begin{array}{l}\text { Sources connect to the } \\
\text { overall argument }\end{array}$ \\
\hline Hitting paywalls & $\begin{array}{l}\text { Proximity or location of } \\
\text { terms }\end{array}$ & $\begin{array}{l}\text { Title (use of emotion, } \\
\text { relevance) }\end{array}$ & Well organized \\
\hline $\begin{array}{l}\text { Lack of motivation and } \\
\text { time to conduct research }\end{array}$ & $\begin{array}{l}\text { Scanning and skimming } \\
\text { results }\end{array}$ & $\begin{array}{l}\text { Relevancy to your own } \\
\text { research } \\
\text { question/argument }\end{array}$ & $\begin{array}{l}\text { I don't know what } \\
\text { synthesis is }\end{array}$ \\
\hline Finding data and statistics & Use relevant sources & Source type & \\
\hline $\begin{array}{l}\text { Getting distracted by } \\
\text { irrelevant sources }\end{array}$ & $\begin{array}{l}\text { Agrees with your } \\
\text { argument "side" }\end{array}$ & Peer-reviewed & \\
\hline \multirow{5}{*}{$\begin{array}{l}\text { Navigating library } \\
\text { databases }\end{array}$} & Author credibility & Using library databases & \\
\hline & Assignment requirements & & \\
\hline & Click on some results & & \\
\hline & Ask a librarian for help & & \\
\hline & I don't know & & \\
\hline
\end{tabular}




\section{Tables}

\begin{tabular}{|l|c|c|c|}
\hline & Control & Experiment & Overall \\
\hline Pretest & $95.6 \%$ & $82.2 \%$ & $88.9 \%$ \\
\hline Posttest & $66.7 \%$ & $64.4 \%$ & $65.5 \%$ \\
\hline
\end{tabular}

Table I: Summary of quantitative survey response rates.

\begin{tabular}{|l|c|c|c|c|c|c|c|c|c|}
\hline \multirow{2}{*}{ Survey item } & \multirow{2}{*}{$\mathbf{n}$} & \multirow{2}{*}{ Mean } & SD & \multirow{2}{*}{ Median } & \multicolumn{4}{|c|}{ Distribution } \\
\cline { 6 - 10 } & & & & $\mathbf{1}$ & $\mathbf{2}$ & $\mathbf{3}$ & $\mathbf{4}$ & $\mathbf{5}$ \\
\hline $\begin{array}{l}\text { I am confident in my abilities to use library } \\
\text { resources. }\end{array}$ & 80 & 3.1 & 0.99 & 3 & 3 & 24 & 17 & 34 & 2 \\
\hline $\begin{array}{l}\text { I am confident in my abilities to tell if } \\
\text { information is credible. }\end{array}$ & 80 & 3.8 & 0.95 & 4 & 2 & 9 & 6 & 49 & 14 \\
\hline $\begin{array}{l}\text { I am confident in my abilities to find } \\
\text { appropriate information for a specific topic. }\end{array}$ & 80 & 3.84 & 0.93 & 4 & 0 & 9 & 15 & 36 & 20 \\
\hline $\begin{array}{l}\text { I am confident in my abilities to meaningfully } \\
\text { combine my research into a cohesive paper. }\end{array}$ & 80 & 3.69 & 1.03 & 4 & 4 & 6 & 16 & 39 & 15 \\
\hline $\begin{array}{l}\text { I think the library sessions for this class will } \\
\text { be useful for me. }\end{array}$ & 80 & 4.14 & 0.88 & 4 & 1 & 3 & 11 & 34 & 31 \\
\hline
\end{tabular}

Table II: Student baseline before library instruction, where 1 is "Strongly disagree," 2 is "Somewhat disagree," 3 is "Neither agree nor disagree," 4 is "Somewhat agree," and 5 is "Strongly agree."

\begin{tabular}{|c|c|c|c|c|c|c|c|c|c|}
\hline \multicolumn{5}{|c|}{ Using Library Resources } & \multicolumn{5}{|c|}{ Assessing Credibility } \\
\hline \multirow[t]{5}{*}{ BW } & & $d f$ & $F$ & $p$ & BW & & $d f$ & $F$ & $p$ \\
\hline & Con & 1 & .10 & $n s$ & & Con & 1 & .30 & $n s$ \\
\hline & Time & 1 & 1.25 & $n s$ & & Time & 1 & 1.18 & $n s$ \\
\hline & Con $\mathrm{x}$ & 1 & 2.87 & $n s$ & & Con $\mathrm{x}$ & 1 & .05 & $n s$ \\
\hline & Time & & & & & Time & & & \\
\hline \multirow[t]{4}{*}{ WI } & & & & & WI & & & & \\
\hline & Time & 1 & 57.23 & $<.001$ & & Time & 1 & 31.73 & $<.001$ \\
\hline & Con $\mathrm{x}$ & 1 & .22 & $n s$ & & Con $\mathrm{x}$ & 1 & 1.98 & $n s$ \\
\hline & Time & & & & & Time & & & \\
\hline
\end{tabular}

\begin{tabular}{|c|c|c|c|c|c|c|c|c|c|}
\hline \multicolumn{5}{|c|}{ Finding Information } & \multicolumn{5}{|c|}{ Synthesizing Research } \\
\hline \multirow[t]{5}{*}{ BW } & & $d f$ & $F$ & $p$ & \multirow[t]{5}{*}{ BW } & & $d t$ & $F$ & $p$ \\
\hline & Con & 1 & .89 & $n s$ & & Con & 1 & .68 & $n s$ \\
\hline & Time & 1 & .35 & $n s$ & & Time & 1 & .31 & $n s$ \\
\hline & Con $\mathrm{x}$ & 1 & 1.45 & $n s$ & & Con $\mathrm{x}$ & 1 & .04 & $n s$ \\
\hline & Time & & & & & Time & & & \\
\hline \multirow{2}{*}{ WI } & Time & 1 & 29.67 & $<.001$ & \multirow{2}{*}{ WI } & Time & 1 & 13.17 & $<.001$ \\
\hline & $\begin{array}{l}\text { Con } x \\
\text { Time }\end{array}$ & 1 & 1.06 & $n s$ & & $\begin{array}{l}\text { Con } x \\
\text { Time }\end{array}$ & 1 & .37 & $n s$ \\
\hline
\end{tabular}

Table III: Results summary. Note: Con = Condition. 


\begin{tabular}{|l|c|c|c|c|c|c|c|c|c|}
\hline \multirow{2}{*}{ Survey item } & \multirow{2}{*}{$\boldsymbol{N}$} & $\boldsymbol{M}$ & $\boldsymbol{N} \boldsymbol{S} \boldsymbol{N}$ & \multirow{2}{*}{ Median } & \multicolumn{5}{|c|}{ Distribution } \\
\cline { 5 - 10 } & & & & & $\mathbf{1}$ & $\mathbf{2}$ & $\mathbf{3}$ & $\mathbf{4}$ & $\mathbf{5}$ \\
\hline I liked using case studies to learn research skills. & 29 & 3.14 & 1.38 & 3 & 5 & 5 & 5 & 9 & 5 \\
\hline My case study taught me skills I can use in my own research. & 29 & 3.86 & 1.06 & 4 & 1 & 3 & 3 & 14 & 8 \\
\hline
\end{tabular}

Table IV: Posttest experimental student attitudes toward the CBL curriculum, where 1 is "Strongly disagree," 2 is "Somewhat disagree," 3 is "Neither agree nor disagree," 4 is "Somewhat agree," and 5 is "Strongly agree."

\begin{tabular}{|c|c|c|}
\hline \multirow{4}{*}{$\begin{array}{l}\text { Survey item } \\
\text { After rating level of } \\
\text { agreement with this } \\
\text { statement ("I liked } \\
\text { using case studies to } \\
\text { learn research } \\
\text { skills."), tell us more. }\end{array}$} & \multicolumn{2}{|c|}{ Summary of responses } \\
\hline & Negative & $\begin{array}{l}\text { - Wanted to focus on personal research } \\
\text { - Three days with same case study was too long-winded } \\
\text { - Case studies were difficult when they were claims of value rather than } \\
\text { fact } \\
\text { - Wanted more realistic (rather than "wacky") sources }\end{array}$ \\
\hline & Middle & $\begin{array}{l}\text { - Appreciated simplistic case studies and understood reasoning behind } \\
\text { lessons } \\
\text { - Difficult to maintain focus over three days } \\
\text { - Wanted more time in the library }\end{array}$ \\
\hline & Positive & $\begin{array}{l}\text { - Having a topic provided and group work created a fun rather than } \\
\text { intimidating environment } \\
\text { - } \quad \text { Case studies allowed lower stakes practice } \\
\text { - } \quad \text { Showed that research could still be done on a "silly" topic } \\
\text { - } \quad \text { Did sometimes get frustrated } \\
\text { - Some did not enjoy assigned case study and would have like to choose }\end{array}$ \\
\hline \multirow{3}{*}{$\begin{array}{l}\text { After rating level of } \\
\text { agreement with this } \\
\text { statement ("My case } \\
\text { study taught me skills } \\
\text { I can use in my own } \\
\text { research."), tell us } \\
\text { more. }\end{array}$} & Negative & $\begin{array}{l}\text { - } \quad \text { Stuck in a loop with case study } \\
\text { - } \quad \text { Good lesson, but too long-winded } \\
\text { - } \quad \text { Didn't help me learn because I wasn't interested in the topic } \\
\text { - } \quad \text { Liked synthesis and matrix }\end{array}$ \\
\hline & Middle & $\begin{array}{ll}\text { - } & \text { Felt like busywork } \\
\text { - } & \text { Sometimes unsure what I was supposed to be learning } \\
\text { - } & \text { Knew most of the material already }\end{array}$ \\
\hline & Positive & $\begin{array}{l}\text { - Learnt skills, but wanted to apply to own research } \\
\text { - } \quad \text { Working in groups made transfer more difficult } \\
\text { - } \quad \text { Learned how to not get distracted by irrelevant (but credible) sources } \\
\text { - } \quad \text { Aparned how to evaluate and find credible sources } \\
\text { - } \quad \text { Rearching } \\
\text { - } \quad \text { Liked syntrefresheris } \\
\text { - } \quad \text { Would have understood more with a different case study }\end{array}$ \\
\hline
\end{tabular}

Table V: Student responses to the CBL approach. 


\begin{tabular}{|c|c|c|c|c|}
\hline & $\begin{array}{l}\text { Pretest } \\
\text { Experiment }\end{array}$ & $\begin{array}{l}\text { Posttest } \\
\text { Experiment }\end{array}$ & $\begin{array}{l}\text { Pretest } \\
\text { Control } \\
\end{array}$ & $\begin{array}{l}\text { Posttest } \\
\text { Control } \\
\end{array}$ \\
\hline \multicolumn{5}{|l|}{ Search Struggles } \\
\hline Finding relevant information & $38.9 \%$ & $31.0 \%$ & $54.8 \%$ & $36.7 \%$ \\
\hline Finding credible sources & $30.6 \%$ & $24.1 \%$ & $45.2 \%$ & $6.7 \%$ \\
\hline Selecting the right keywords & $5.6 \%$ & $10.3 \%$ & $0.0 \%$ & $13.3 \%$ \\
\hline Sorting through, filtering too many results & $13.9 \%$ & $3.4 \%$ & $9.5 \%$ & $10.0 \%$ \\
\hline Getting distracted by irrelevant sources & $0.0 \%$ & $6.9 \%$ & $0.0 \%$ & $10.0 \%$ \\
\hline Lack of motivation, time to conduct research & $0.0 \%$ & $3.4 \%$ & $14.3 \%$ & $10.0 \%$ \\
\hline Finding a "specific" piece of information & $8.3 \%$ & $10.3 \%$ & $16.7 \%$ & $10.0 \%$ \\
\hline Finding and reading scholarly articles & $16.7 \%$ & $10.3 \%$ & $2.4 \%$ & $3.3 \%$ \\
\hline \multicolumn{5}{|l|}{ Search Strategies } \\
\hline Be more specific, narrow focus, adjust scope & $34.3 \%$ & $14.3 \%$ & $40.5 \%$ & $23.3 \%$ \\
\hline Add or modify keywords & $57.1 \%$ & $64.3 \%$ & $59.5 \%$ & $80.0 \%$ \\
\hline Use database filters or tools & $11.4 \%$ & $42.9 \%$ & $14.3 \%$ & $30.0 \%$ \\
\hline \multicolumn{5}{|l|}{ Evaluation Strategies } \\
\hline Author's credibility & $65.7 \%$ & $86.2 \%$ & $57.1 \%$ & $86.7 \%$ \\
\hline Reputation/credibility of publication & $48.6 \%$ & $41.4 \%$ & $57.1 \%$ & $40.0 \%$ \\
\hline Website domain & $20.0 \%$ & $10.3 \%$ & $28.6 \%$ & $16.7 \%$ \\
\hline Bias in the author, article, or publication & $34.3 \%$ & $13.8 \%$ & $7.1 \%$ & $6.7 \%$ \\
\hline Currency & $17.1 \%$ & $37.9 \%$ & $40.5 \%$ & $70.0 \%$ \\
\hline Investigate claim through other sources & $8.6 \%$ & $10.3 \%$ & $16.7 \%$ & $10.0 \%$ \\
\hline Fact check the article's sources & $20.0 \%$ & $31.0 \%$ & $33.3 \%$ & $30.0 \%$ \\
\hline Title (use of emotion, relevance) & $17.1 \%$ & $3.4 \%$ & $0.0 \%$ & $0.0 \%$ \\
\hline $\begin{array}{l}\text { Relevancy to your own research } \\
\text { question/argument }\end{array}$ & $8.6 \%$ & $20.7 \%$ & $11.9 \%$ & $13.3 \%$ \\
\hline \multicolumn{5}{|l|}{ Synthesis Explanations } \\
\hline $\begin{array}{l}\text { Balanced conversation between author's } \\
\text { voice and sources }\end{array}$ & $8.8 \%$ & $57.1 \%$ & $14.3 \%$ & $46.7 \%$ \\
\hline Author's voice is dominant & $5.9 \%$ & $0.0 \%$ & $2.4 \%$ & $36.7 \%$ \\
\hline Combining of ideas & $0.0 \%$ & $10.7 \%$ & $0.0 \%$ & $20.0 \%$ \\
\hline Citing multiple sources & $5.9 \%$ & $35.7 \%$ & $9.5 \%$ & $40.0 \%$ \\
\hline Good "flow," easy to read & $17.6 \%$ & $7.1 \%$ & $16.7 \%$ & $6.7 \%$ \\
\hline I don't know what synthesis is & $26.5 \%$ & $0.0 \%$ & $31.0 \%$ & $0.0 \%$ \\
\hline
\end{tabular}

Table VI: Notable changes in the frequencies of codes by time and condition. 